Журнал«Герстективита інновації наукц»

(Серія «Гедагогіка», Серія «Гиихологія», Серія «Медицина»

№2(7) 2022

УДК 37.015.31«19/20»:613.42(045)

https://doi.org/10.52058/2786-4952-2022-2(7)-488-499

Онипченко Оксана Ігорівна доктор педагогічних наук, доцент, професор кафедри соціальної роботи, Комунальний заклад «Харківська гуманітарнопедагогічна академія» Харківської обласної ради, пров. Руставелі, 7, м. Харків, 61000, тел.: (057) 732-87-33, https://orcid.org/0000-0002-5682-7897

Волкова Катерина Сергіївна кандидат педагогічних наук, доцент, завідувач кафедри соціальної роботи, Комунальний заклад «Харківська гуманітарно-педагогічна академія» Харківської обласної ради, пров. Руставелі, 7, м. Харків, 61000, тел.: (057) 732-87-33, https://orcid.org/0000-0003-1905-3295

Воровка Маргарита Іванівна доктор педагогічних наук, доцент кафедри педагогіки і педагогічної майстерності, Мелітопольський державний педагогічний університет імені Богдана Хмельницького, вул. Гетьманська, 20, м. Мелітополь, 72300, тел.: (0619) 44-04-64, https://orcid.org/0000-0002-9651-0990

\title{
ФОРМУВАННЯ ІНКЛЮЗИВНОГО СЕРЕДОВИЩА ЗА ДОПОМОГОЮ ІГРОВОЇ ТЕРАПІЇ, ІГРАШОК
}

Анотація. У статті обгрунтовується необхідність формування інклюзивного середовища, зокрема за допомогою ігрових технологій. Вказано на неприпустимість дискримінації стосовно осіб з інвалідністю, що досягається забезпеченням однакового ставлення до всіх людей; підкреслюється важливість створенням безбар'єрного освітнього середовища.

Розв'язуючи питання про способи соціалізації, соціально-психологічної реабілітації дітей з інвалідністю, авторки статті зазначають, що цей процес може мати ігрову форму. Показано, що одним зі способів створення такого ігрового процесу можуть служити близькі дитині образи масової культури, а також сучасні інтерактивні технології.

Зазначено, що особливості дітей 3 інвалідністю змушують шукати нестандартні форми активізації мови, комунікативності, розвитку пізнавальної діяльності. У зв'язку з чим розглянуто теоретичні основи творчої (соціокультурної) реабілітації дітей з інвалідністю на прикладі деяких елементів ігрової терапії (комплекс реабілітаційних ігрових методик, форм, засобів, ситуацій).

Обгрунтовано один 3 дієвих видів ігрової терапії - лялькотерапія, який рекомендується як метод краще застосовувати 3 дошкільниками й молодшими школярами.

Авторками вказано, що у зв'язку зі спрямуванням освіти на створення безбар'єрного середовища, а також 3 метою реабілітації та соціалізації дітей 3 
інвалідністю, останне десятиліття почали з'являтися нові іграшки, які відбивають інклюзивну культуру. У зв'язку з чим була придумана за участі групи експертів, куди входили педіатри, психологи, батьки й діти 3 інвалідністю, нова серія іграшок, що зображує людей з різними фізичними вадами: ляльки на інвалідних візках, ляльки 3 протезами, ляльки 3 хворобами шкіри, синдромом Дауна тощо.

Вважається, що ляльки з обмеженими можливостями досить корисні в плані формування інклюзивного середовища (хоча ставлення до таких іграшок в суспільстві неоднозначно). Такі іграшки дозволяють із раннього віку виховувати толерантність до людей, які мають подібні обмеження. Крім того, «ляльки 3 інвалідністю» частіше застосовуються в психотерапії при роботі 3 дітьми $з$ інвалідністю.

Ключові слова: інклюзивне середовище, безбар'єрне середовище, діти 3 інвалідністю, ігротерапія, лялькотерапія, іграшки з інвалідністю.

Onypchenko Oksana Ihorivna Doctor of Pedagogy, Associate Professor, Professor of the Department of Social Work of the Municipal establishment «Kharkiv Humanitarian Pedagogical Academy» of the Kharkiv Regional Council St., Rustavely, 7, Kharkiv, 61000, tel.: (057) 732-87-33, https://orcid.org/0000-0002-5682-7897

Volkova Kateryna Serhiivna Candidate of Pedagogical Sciences, Associate Professor, Head of of the Department of Social Work of the Municipal establishment «Kharkiv Humanitarian-Pedagogical Academy» of Kharkiv Regional Council, Rustavely St., 7, Kharkiv, 61000, tel.: (057) 732-87-33, https://orcid.org/0000-0003-1905-3295

Vorovka Marharyta Ivanivna Doctor of Pedagogy, Associate Professor, of the Department of Pedagogy and Pedagogical Mastership, Melitopol State Pedagogical University named after Bogdan Khmelnitsky, Hetmanska St., 20, Melitopol, 72300, tel.: тел. (0619) 44-04-64, https://orcid.org/0000-0002-9651-0990

\section{FORMATION OF INCLUSIVE ENVIRONMENT FOR BY GAME THERAPY, TOYS}

Abstract. The article substantiates the need to create an inclusive environment, in particular with the help of game technologies. The inadmissibility of discrimination against persons with disabilities, which is achieved by ensuring equal treatment of all people, is pointed out; the importance of creating a barrier-free educational environment is emphasized.

Addressing the issues of ways of socialization, social and psychological rehabilitation of children with disabilities, the authors of the article note that this process can take the form of a game. It is shown that one of the ways to create such a game process can be images of mass culture close to the child, as well as modern interactive technologies. It is noted that the peculiarities of children with disabilities 
make us look for non-standard forms of language activation, communication, development of cognitive activity. In this regard, the theoretical foundations of creative (socio-cultural) rehabilitation of children with disabilities are considered on the example of some elements of game therapy (a set of rehabilitation game techniques, forms, tools, situations). One of the effective types of game therapy is substantiated - puppet therapy, which is recommended as a method to be better used with preschoolers and younger students.

The authors point out that due to the focus of education on creating a barrier-free environment, as well as the rehabilitation and socialization of children with disabilities, new toys that reflect an inclusive culture have begun to appear in the last decade. In this regard, it was invented with the participation of a group of experts, which included pediatricians, psychologists, parents and children with disabilities, a new series of toys depicting people with various disabilities: dolls in wheelchairs, dolls with prostheses, dolls with skin diseases, Down syndrome, etc.

It is believed that dolls with disabilities are quite useful in terms of creating an inclusive environment (although the attitude to such toys in society is ambiguous). Such toys allow to develop tolerance to people who have similar restrictions from an early age. In addition, "dolls with disabilities" are more commonly used in psychotherapy when working with children with disabilities.

Keywords: inclusive environment, barrier-free environment, children with disabilities, game therapy, puppet therapy, toys with disabilities.

Постановка проблеми. Визнання державою цінності соціальної та освітньої інтеграції дітей з інвалідністю обумовлює необхідність створення для них безбар'єрного середовища, зокрема в системі освіти.

Ступінь взаємодії дитини із суспільством залежить не тільки від соціального середовища, виховання й особистих якостей, але й від набутого нею досвіду подібної взаємодії. У зв'язку із чим виникає питання про способи соціалізації, адаптації та реабілітації дітей з інвалідністю, а також формування для усіх членів суспільства інклюзивного середовища.

Аналіз останніх досліджень і публікацій. Зарубіжний досвід інклюзивної освіти переконливо свідчить про неприпустимість дискримінації стосовно осіб 3 інвалідністю, про забезпечення однакового ставлення до всіх людей, а також про доцільність створення безбар'єрного освітнього середовища.

Інклюзивна модель освіти, згідно 3 міжнародними документами, має забезпечити соціальний, емоційний та когнітивний розвиток особистості через урахування потенційних можливостей та індивідуальних особливостей розвитку кожної особи, щоб вона відчувала себе неповторним, повноцінним суб'єктом соціального середовища [11, С. 215].

Успішна реалізація провідних засад інклюзивного підходу до організації освітнього процесу в Україні стає можливим завдяки науковим доробкам як зарубіжних (Г. Аспергер, Е. Еріксон, Л. Каннер, Д. Мартін, А. Маслоу, С. Столл, К. Роджерс та ін.), так і вітчизняних (М. Андреєва, В. Бондар, Б. Братусь, 
Т. Гладун, А. Колупаєва， І. Кузава，О. Рассказова， Н. Софій， М. Чайковський, А. Шевцов, О. Ферт та ін.) дослідників. У їх працях обгрунтовано принципові положення розбудови інклюзивного освітнього середовища, висвітлено специфіку соціалізації осіб із інвалідністю в умовах інклюзивної освіти, проаналізовано технологію розвитку соціальності.

Меті статті - показати необхідність створення інклюзивного середовища за допомогою нових ігрових технологій, нових іграшок; розглянути нестандартні форми роботи 3 дітьми 3 інвалідністю; охарактеризувати ігрову терапію, як комплекс реабілітаційних ігрових методик, форм, засобів, ситуацій, а також один із його дієвих видів - лялькотерапія.

Виклад основного матеріалу. Концепція інклюзивної освіти, відображаючи одну з головних демократичних ідей світу, грунтується на тому, що всі діти - цінні й активні члени суспільства. Тому організація інклюзивного освітнього простору має будуватися на таких складових, як інклюзивна культура, інклюзивна політика та інклюзивна практика.

Інклюзивна культура, спираючись на інклюзивні цінності, $\epsilon$ носієм філософії інклюзивної освіти та $є$ загальною для всіх, хто забезпечує освітній процес і соціальне забезпечення. А спосіб упровадження інклюзивної освіти стає відчутним для всіх учасників співтовариства.

Інклюзивна політика відображає інклюзію у всіх нормативно-правових та поточних документах закладів освіти та соціального забезпечення, їх стратегіях та інституційному розвитку. Документи, мають передбачати чіткі стратегії розвитку дитини та інклюзивного простору, у якому вона перебуває.

Інклюзивне навчання ставить серйозні завдання перед освітньою системою i функціонуванням закладу освіти, мобілізує до злагодженості роботи колективу, до вдосконалення програм і методів навчання, стимулюючи розвиток компетенції вчителів, психологів, працівників соціальної сфери та інших фахівців [6].

Інклюзивна культура буває зовнішня та внутрішня. Зовнішня інклюзивна культура - це організація освітнього простору відповідно до принципів доступності та безпеки; адаптовані освітні програми, спеціальні методи навчання і виховання, підручники, навчальні посібники, дидактичні матеріали, технічні засоби, команда фахівців та ін.

Внутрішня структура інклюзивної культури закладу освіти або установи соціального забезпечення - це ціннісно-смислові основи інклюзивної політики і практики освітньої організації (або соціального забезпечення), норми відносин суб'єктів освітнього процесу (система уявлень, установок, правил, цінностей і моделей поведінки тощо).

Дитинство $є$ найважливішим етапом в житті людини, у якому відбувається формування особистості в цілому й основних соціальних навичок зокрема. Соціальним аспектом цінності життя дитини, зокрема дитини з інвалідністю $\epsilon$ прийняття іï навколишніми й досягнення взаєморозуміння між нею, однолітками й світом дорослих. 
Необхідно пам'ятати, що дитинство аж ніяк не $є$ етапом «підготовки до дорослого життя», що це й $є$ власне життя, із властивими йому соціальною й екзистенціальною кризами, у період яких дитина в процесі самосвідомості випробовує кризу особистості, запитуючи себе й навколишніх: «Хто я?», «Яка я?», «Чому я така?», «Що буде, коли я подорослішаю?» та ін. Немаловажний і той факт, що «моральність суспільства визначається його ставленням до дітей» [10, С.70].

Розв'язуючи питання про способи соціалізації, соціально-психологічної реабілітації дітей з інвалідністю, слід зазначити, що цей процес може мати ігрову форму. «У кожному разі він повинен захоплювати дитину й бути цікавим і веселим» [10, С.71]. Одним зі способів створення такого ігрового процесу можуть служити близькі дитині образи масової культури, а також сучасні інтерактивні технології.

Згідно 3 дослідженнями, доведено, що ретельно та ефективно сплановане освітнє середовище може суттєво покращувати взаємодію між дітьми: використання іграшок та видів діяльності, що передбачає соціальну взаємодію (наприклад, виготовлення спільного колажу), об'єднання дітей із порушеннями розвитку зі своїми однолітками може суттєвим чином вплинути на частоту та тривалість позитивної взаємодії між ними (Т. Бові і П. Стрейн, 2005) [8, С.10].

Розрізняють три взаємопов'язані компоненти освітнього середовища у дошкільних групах: фізичне середовище (організація і дизайн групової кімнати, що охоплює центри діяльності, навчальні матеріали, іграшки, меблі), соціальне середовище (взаємодія, яка відбувається у дошкільній групі між дітьми, дітьми і педагогами, дітьми, педагогами і батьками), структурне середовище (час, послідовність, тривалість видів діяльності впродовж дня).

Для того, щоб середовище сприяло розвитку і навчанню дітей, потрібно, щоб кожен із цих компонентів був ретельно продуманий і реалізований. Окрім цього, кожен аспект освітнього середовища має відображати філософію закладу освіти і цілі навчальної програми [8, С.11].

Особливості дітей з інвалідністю змушують шукати нестандартні форми активізації мови, комунікативності, розвитку пізнавальної діяльності.

Розглянемо теоретичні основи творчої (соціокультурної) реабілітації дітей 3 інвалідністю на прикладі деяких елементів ігрової терапії.

Ігрова терапія - це комплекс реабілітаційних ігрових методик, форм, засобів, ситуацій. Нерідко ігротерапія розглядається як засіб для розкріпачення патологічних психічних станів людини. Будучи унікальним засобом комплексної реабілітації, цей метод може виконувати функції соціалізації, розвитку, виховання, адаптації, релаксації, рекреації й ін. [9, С. 36].

Специфіка ігротерапії в тому, що життєві обставини, що травмують, переживаються (програються) в умовному, ослабленому виді, хоча їх емоційне відбиття (катарсис) $є$ досить реальним. За допомогою ігротерапії можна випробувати типи поведінки, відокремивши ті, що найбільш підходять конкретній особистості в певній життєвій ситуації. Саме рольова поведінка відбиває психологічний стан і функціональні тенденції людини з інвалідністю. 
Важливим привілеєм ігротерапії є корекція й розвиток взаємин. 3 метою змінити ставлення людини 3 інвалідністю до себе й до інших, поліпшити психологічне самопочуття (підвищити самооцінку), соціометричний статус, емоційне мікросередовище, застосовуються дві форми ігротерапії: спрямована (директивна) i ненаправлена (недирективна). Використання спрямованої ігротерапії вимагає особистої участі фахівця у грі. При цьому застосовуються методичні прийоми й ігри зі структурованим ігровим матеріалом і сюжетом у вигляді педагогічно організованих сюжетно-рольових ігор. Під час цих ігор діти з інвалідністю самі створюють ролі й ігрові ситуації з відтворенням діяльності й взаємин у соціумі $[9$, с.36].

До видів спрямованої ігротерапії відносимо такі: ігри-драматизації, пізнавальні ігри, конкурси, турніри, змагання, заняття в театральних і лялькових гуртках, арт-ігри, ігри рухливі, імпровізаційні. Застосування спрямованої ігротерапії орієнтоване на самостійну гру.

Такий вид ігрової діяльності дозволяє вирішувати наступні корекційні завдання: розширення репертуару самовираження; досягнення саморегуляції й емоційної стійкості; корекція відносин.

В процесі ігротерапії спілкування $є$ своєрідним засобом налагодження взаємин дитини з інвалідністю з навколишнім світом.

Ненаправлена ігротерапія орієнтована на самостійну гру дитини 3 інвалідністю, під час якої вона виражає свій внутрішній світ, самопочуття. Це потребує наявності сюжетів, що самостійно організовуються й розвиваються: імпровізації, творів тощо.

В цьому процесі роль дорослого зводиться до мінімуму: організація атмосфери взаєморозуміння, емоційне співпереживання, установлення правил та обмежень у грі. Отже, дорослий може виступати як рівноправний партнер, що підкоряється правилам гри, що знімає дистанцію між ним і дитиною, розкріпачуючи останню.

Одним 3 дієвих видів ігрової терапії є лялькотерапія, який як метод краще застосовувати $з$ дошкільниками й молодшими школярами.

Перед тим як почати гру фахівець спілкується 3 дитиною, іiі батьками та педагогом, вислуховує скарги й з'ясовує специфіку характеру дитини, умови життя й визначає причини виникнення проблем дитини. Після цього готує сценарій гри за участю ляльок, який непомітно й делікатно відтворює психотравмуючу ситуацію [9, с.37].

У зв'язку зі спрямуванням освіти на створення безбар'єрного середовища, а також 3 метою реабілітації та соціалізації дітей 3 інвалідністю, останнє десятиліття почали з'являтися нові іграшки.

«Гграшки відбивають нашу культуру, і оскільки світ усе більше розуміє важливість інклюзивності, ми усвідомили, що настав час створити нову лінійку ляльок», - сказала Кім Калмон - перший заступник голови Mattel Fashion Doll Design.

Нова лінійка Creatable World, як повідомила компанія, була придумана за участі групи експертів, куди входили педіатри, психологи, батьки й діти з інвалідністю. 
Нещодавно одна 3 американських компаній, що виробляють іграшки, випустила серію ляльок типу «барбі», що зображує людей з різними фізичними вадами: ляльки на інвалідних візках, ляльки з протезами, ляльки з хворобами шкіри. За твердженням розробників, такі іграшки мають виховувати в дітях толерантне ставлення до людей з інвалідністю.

Виробник Барбі компанія Mattel запускає нову лінійку ляльок, яка покликана відбити «різноманітний погляд на красу» та інклюзивність. Нова серія містить у собі Барбі без волосся, а також із пігментацією шкіри - ознаками хвороби вітіліго. Для створення цієї ляльки Mattel працювала 3 дерматологами, щоб гарантувати правильне відображення вітіліго.

Як заявляє Mattel, компанія прагне «переосмислити, що значить бути Барбі або виглядати, як Барбі», додавши, що це дозволить дітям «грати ще більше історій, які вони бачать у навколишньому їхньому світі» [4, с. 1].

У новій лінійці також $є$ Барбі 3 протезом. Ця лялька була створена в колаборації з Джордан Рівз - 12-літньою дівчинкою 3 протезом руки, яка займається допомогою людям із інвалідністю. Також бренд включив у лінійку другу ляльку з більш темним відтінком шкіри, у неї золотий протез ноги [4, с. 3].

У Великобританії за останній рік однією з найбільш продаваних моделей стала лялька Барбі на інвалідному візку.

Вважається, що ляльки з обмеженими можливостями досить корисні в плані формування інклюзивного середовища. Такі іграшки дозволяють із раннього віку виховувати толерантність до людей, які мають подібні обмеження. Крім того, «ляльки 3 інвалідністю» частіше застосовуються в психотерапії при роботі з дітьми з інвалідністю. Вважається, що дитина, яка втратила кінцівки, граючи 3 такої лялькою, не почуває себе неповноцінною: «Вона така ж, як я!» - думає вона. У Британії так само існує лялькова лінійка «Як Я!». А для хлопчиків - набори Лего з інвалідними візками й гоночні візки як аксесуари для ляльок. Також є лінійка іграшкових протезів і фіксаторів [7].

Не менш важливою групою іграшок стали ляльки, що відтворюють своєю зовнішністю дітей з різними хворобами, приміром, із синдромом Дауна. Такі ляльки наділені маленькими, притиснутими до голови вухами, укороченими пальцями, злегка висунутим язиком й мигдалеподібними очима. Крім того, на грудях у них помітний «слід» від операційного втручання, оскільки приблизно половина дітей із хромосомними захворюваннями народжується 3 дефектами серця, пише Daily Telegraph.

Раніше дітям із синдромом Дауна не було, із чим себе ідентифікувати. Вони бачать, що ляльки зовсім інші, ніж вони, i, як і всі діти, прагнуть себе із кимось співвіднести. Так заявила Донна Мур (Donna Moore), викладач із Південної Кароліни, коли відкривала першу фірму, що спеціалізується на виробництві ляльок з видимим синдромом Дауна. Пізніше її ідею підхопили інші. На жаль, не завжди в позитивному ключі. Так, у магазини шведського підприємця Гетеборга, потрапила схожа іграшка від компанії Göteborgskooperativet för independent living (GIL), в інструкції до якої було написано: «Поводься з нею, як 
iз дурником». Однак як явище в цілому подібні іграшки призначені для того, щоб діти з раннього віку звикли до позитивного сприйняття будь-якого члена суспільства.

Sibahle Collection - одна з компаній, діяльність яких спрямована на випуск ляльок з різноманітною зовнішністю. Керолайн Хлахла й Хуліла Вілаказі-Офосу заснували свою фірму в 2016 році й уже встигли подарувати світу кілька серій ляльок $з$ темною й смаглявою шкірою та всілякими особливостями зовнішності. Фундаторки вважають, що в кожної маленької дівчинки $є$ право на ляльку, яка була б схожа на неї. Особливо це стосується тих випадків, коли є особливості зовнішності, наприклад, вітіліго або альбінізм. І, як показала практика, це правильний шлях: на одній із виставок вони побачили жінку похилого віку, яка плакала, стоячи біля вітрини з їхньою лялькою-альбіносом. За ії словами, якби така іграшка була в неї в дитинстві, це могло б змінити ії життя. Вона почувала б, що не самотня, що є хтось, хто на неї схожий.

Компанія дає всім створеним персонажам імена. Для цього використовуються різні африканські слова, пов'язані з красою. Лялька з вітіліго одержала ім'я Нданака, що перекладається з однієї з африканських говірок як «Я прекрасна». Це саме те, що Керолайн і Хуліла прагнуть нагадати кожній дитині: будь-яка людина прекрасна, незалежно від того, якою створила іiі природа.

Також $\epsilon$ іграшки, які вказують на небайдужість до проблеми дитячої онкології. Провідний виробник ляльок Барбі компанія Mattel підтримала ідею користувачів Facebook «Барбі без волосся» і вже запускає виробництво таких іграшок (як повідомляе американський телеканал CBS6). Виробники вважають, що така лялька зможе допомогти дітям, які втратили волосся після хіміотерапії, почувати себе «нормальними» і швидко адаптуватися до нових обставин свого життя. «Голомоза Барбі» буде поставлятися з комплектом перук, капелюшків, шарфів та інших аксесуарів. Також свого часу виходили ляльки Братц, присвячені проблемі онкології.

Це далеко не весь перелік іграшок, які покликані ознайомити дитину 3 різноманітністю сучасного суспільства й навчити ऑї вільно розрізняти відмінності інших людей. Вони повинні бути в кожному дитячому садку, щоб якнайбільше дітей дошкільного віку мали до них доступ і можливість не тільки самоідентифікації, але й ігрової соціалізації. У такий спосіб толерантне ставлення не буде нав'язаним і не залишатиметься порожнім звуком під час виховних бесід - воно ненав'язливо ввійде до повсякденних ігор, ознайомивши дитину з різними статеворольовими моделями, які трапляться їй у майбутньому.

Але слід відзначити, що в суспільстві питання випуску іграшок з різними фізичними вадами («іграшок 3 інвалідністю») сприймається досить неоднозначно, й слід відмітити аргументи як «за», так і «проти» поширення таких іграшок.

Наприклад, мати дитини 3 інвалідністю, член асоціації громадських об’єднань батьків дітей з інвалідністю, Маргарита Урманчеєва настроєна досить 
скептично: «Мені дуже сподобалася соціальна реклама, у якій дівчинку навчають толерантного ставлення до людей 3 інвалідністю. У іiі ляльки відірвалися окремі частини, і дитині було зрозуміло, що улюблена іграшка залишилася колишньою, незважаючи на те, що в неї тепер немає, наприклад, руки. Що стосується ляльки, відразу випущеної «з інвалідністю», то в цьому випадку дитячі психологи повинні задуматися, наскільки діти будуть асоціювати iї з реальним життям. I, напевно, краще виховувати нормальне ставлення до людей з різними порушеннями на життєвих прикладах...» [5, С. 2].

Так само Тамара Цинцадзе, мати сімох дітей, уважає, що ці ляльки чергове божевілля: «Одна справа - любити свою іграшку, стару, затріпану, запрану, пришивати лапи, що відірвалися, і гудзика замість очей і продовжувати любити. Скільки раз ми це спостерігали. Цей прояв відповідальності, прихильності. Інша справа - створювати свідомо «хвору» іграшку: це нічого не дасть для щиросердечного розвитку дитини, скоріше, нашкодить» [5, С. 2]. Вона вважає, що для людей 3 обмеженими можливостями здоров'я необхідно створювати безбар'єрне середовище завжди й скрізь - наприклад, на вулиці, на дитячому майданчику й удома.

Абсурдною ідею ляльок з імітацією фізичних відхилень для виховання в дітей правильного ставлення до людей з такими проблемами вважає Олександр Кирилов - масажист при Інституті остеопатії, який працює в тому числі й 3 дітьми з інвалідністю. Він зазначає, що в нього викликає відторгнення фабричне виробництво таких ляльок: «Мені здається, що спеціальне виготовлення «калічних» іграшок може призвести до колекціонування «каліцтв», до порівняльних змагань - у кого крутіший «інвалід»» [5, С. 3].

Олександр уважає, що краще запропонувати дітям ситуацію, де звичайна лялька буде обіграватися як людина з інвалідністю. Для цього можна випустити іграшкові крісла-візки, милиці й подібний медичний реманент. Можна просто замотати ніжку або ручку, імітуючи ушкодження. Діти й так відіграють подібним чином з ляльками, у яких відвалилася або зламалася якась частина.

А от священик Феодосій Амбарцумов, названий батько дев'ятьох дітей, вісім з яких із інвалідністю, відзначає, що, імовірно, така лялька все-таки може позитивно вплинути на дитину й, можливо, такі ляльки дозволять почуватися таким дітям комфортно й захищено.

Розглянемо різноманітні форми участі дитини в грі, під час ігротерапії: 1) дитина як глядач дивиться гру ляльок; 2) дитина $є$ учасником рольової гри, у якій пропонується відіграти або іiі саму, або когось іншого (кривдника, скривдженого, сміливого, боягузливого, доброго, агресивного, маленького, дорослого). Створюється симбіотична пара: дитина - дорослий, слабкий сильний і т. ін.; 3) діти можуть вільно відіграти без спрямування й підказки дорослих, психотерапевт розробляє сценарій гри, виходячи з емоційного стану дитини та враження про iї характер, психічні, соціальні можливості; 4) психотерапевт і педагог можуть стати партнерами або об'єктами гри, переживати в процесі гри психічний стан дитини; 5) діти можуть грати в 
придумані ними ігри, педагог-психотерапевт при цьому направляє й виявляє приховані можливості дитини [9, С. 38].

Серед численних видів ігор особливий інтерес викликають так звані проєктивні ігри. Вони одержали свою назву від поняття «проєкція», тобто від переносу станів внутрішнього світу особистості в зовнішній план, коли людина 3 інвалідністю через рольову дію виражає свої інтереси, думки, переживання, які довгий час носила, приховувала у собі. Для цього реабілітологи, педагоги, психологи й інші фахівці повинні дотримувати таких принципів:

- створення природного стимулювального середовища, у якому людина 3 інвалідністю почуває себе комфортно, захищено, без усякого напруження;

- наявність активної діяльності;

- пожвавлення абстрактних символів (літер, ліній, предметів) для формування позитивних мотивацій;

- реальне проживання штучно створених нею самою або за підказкою іншого ситуацій і самостійний пошук виходу й вирішення проблеми, що виникли.

Проєктивні ігри: ігри-ситуації, ігри-екскурсії, ігри із природним матеріалом, 3 піском, що відбивають будь-які сфери (магазин, перукарня, курінь, незаселений острів, хатина, палац).

Таким чином, можна зазначити, що головною метою соціального розвитку сучасного суспільства $\epsilon$ повага до людського розмаїття, установлення принципів солідарності та безпеки, що забезпечує захист та повну інтеграцію у соціум усіх верств населення, у тому числі й осіб з обмеженими можливостями здоров'я.

Особливості дітей 3 інвалідністю сприяють пошуку нестандартних форм взаємодії із оточенням, комунікативності, розвитку пізнавальної активності. У зв’язку з чим розглянуто ігрову терапію, як комплекс реабілітаційних ігрових методик, форм, засобів, ситуацій. А також обгрунтовано один із дієвих видів ігрової терапії - лялькотерапія, як кращій у роботі 3 дітьми дошкільного та молодшого шкільного віку.

На противагу медичній моделі соціальна модель «розглядає ваду здоров’я як соціальну проблему, а не як характеристику особистості» [6, С. 6], оскільки вона (проблема) створена непристосованістю оточення, включаючи ставлення до людей 3 особливими потребами та виробничі норми, архітектурну безбар'єрність і транспорт. Така модель спрямована на зміни в суспільстві таким чином, щоб воно забезпечувало рівну участь своїх громадян у реалізації своїх прав і надавало їм таку можливість.

Висновки. Мета соціалізації дитини 3 інвалідністю не просто навчити іiі адаптуватися до умов соціуму й бути йому корисною, а й, наскільки це можливо, допомогти їй перетворитися в людину, що усвідомлює свою гідність і безсумнівну цінність. Все це відбувається за умови створення безбар'єрного середовища.

Процес соціалізації дитини 3 інвалідністю $є$ важливим рухом дитини й соціуму назустріч один одному до поступового прийняття дитини 3 
інвалідністю як повноправного учасника соціального життя, що має можливість здобуття освіти, професії, а також право на повноцінне спілкування. У процесі соціалізації, соціально-психологічної реабілітації дитини 3 інвалідністю, крім неї самої й медичного співтовариства, бере активну участь і сім'я, й найближче оточення. Успіх соціалізації, реабілітації значною мірою залежить від їхньої взаємодії. Будь-які методи реабілітації - ігрові методи, зокрема лялькотерапія, параспорт, практика «змішаних» шкіл або домашня освіта тут стануть у пригоді.

\section{Jimepamypa:}

1. Воровка M.I., Онипченко О.I. Функціональний взаємозв'язок рольових, дидактичних та ділових ігор. Науковий журнал «Інноваційна педагогіка». Одеса : Причорноморський науково-дослідний інститут економіки та інновацій. 2021. Вип. 41. С. 96-100.

2. Качалова Т. В. Формування інклюзивної культури закладу вищої освіти. Наукові записки НДУ ім. М. Гоголя. Психолого-педагогічні науки. 2018. № 3. С.35-44.

3. Колупаєва А. А., Савчук Л.О. Діти з особливими потребами та організація їх навчання. Науково-методичний посібник. Серія «Інклюзивна освіта». Київ. 2011. 206 с.

4. Куклы Барби с протезом, без волос и с витилиго... URL: https://www.bbc.com/russian/news-51282229

5. Кукла с ограниченными возможностями здоровья... URL: https://www.rosbalt.ru/ piter/2020/04/08/1837203.html

6. Навчально-методичний посібник «Інклюзивне навчання в закладах загальної середньої освіти: керівництво для тренерів». К. 2018. 274 с. URL : http://posibnyk.nus.org.ua/ theme-4-features-organization-inclusive-educational-environment-principles/

7. Онипченко O.I., Драгунова Т.О. Іграшки, які вчать толерантності. Гендерна політика очима української молоді: матеріали підсумкової конференції XV Регіонального наукового конкурсу молодих вчених, Харків, 28 квітня 2021 р. / [за заг. ред. : Н. В. Бібік, Г. Г. Фесенко]; Харків. нац. ун-т міськ. госп-ва ім. О. М. Бекетова. Харків : ХНУМГ ім. О. М. Бекетова, 2021. 268 с. С. $89-92$

8. Середовище, що належить дітям : порадник для педагогів закладів дошкільної освіти. К., 2019. 81 c.

9. Технологии творческой реабилитации детей с ограниченными возможностями / сост.: А. С. Донченко, Е. Н. Филиппова, Н. В. Холматова. URL : https://depsr.admhmao.ru/ upload/iblock/79e/7._tekhnologiya_tvorcheskoy_reab._detey_s_ogranich._vozmozh..pdf

10.Хубулава $\Gamma$. Г. Ребенок-инвалид и общество: взаимоотношения и социализация. Ортопедия, травматология и восстановительная хирургия детского возраста. URL : file://C:/Users/User/AppData/Local/Temp/7071-7932-2-PB.pdf

11. Volkova K., Bieloliptseva O. Preparation of future pedagogical and social specialists for professional activity in inclusive and gender sensitive environment: Modernization of the pedagogical system of tertiary education in higher education institutions : collective monograph. Kharkiv: Publishing house Education and Science s.r.o., 2021. C. 213-236.

\section{References:}

1. Vorovka M.I., Onypchenko O.I., (2021) Funktsionalnyi vzaiemozviazok rolovykh, dydaktychnykh ta dilovykh ihor [Functional interconnection of role-playing, didactic and business games]. Naukovyi zhurnal «Innovatsiina pedahohika». Odesa : Prychornomorskyi naukovodoslidnyi instytut ekonomiky ta innovatsii. Vyp. 41. S. 96-100. [in Ukrainian].

2. Kachalova T. V., (2018) Formuvannia inkliuzyvnoi kultury zakladu vyshchoi osvity [Formation of inclusive culture of higher education institution]. Naukovi zapysky NDU im. M. Hoholia. Psykholoho-pedahohichni nauky. № 3. S.35-44. [in Ukrainian]. 
3. Kolupaieva A. A., Savchuk L .O., (2011) Dity z osoblyvymy potrebamy ta orhanizatsiia yikh navchannia [Children with special needs and organization of their education]. Naukovometodychnyi posibnyk. Seriia «Inkliuzyvna osvita». Kyiv. 206 s. [in Ukrainian].

4. Barbie dolls with a prosthesis, without hair and with vitiligo [Barbie dolls with a prosthesis, without hair and with vitiligo]. URL: https://www.bbc.com/russian/news-51282229 [in Russian].

5. Doll with disabilities [Doll with disabilities]. URL: https://www.rosbalt.ru/piter/ 2020/04/08/1837203.html [in Russian].

6. Navchalno-metodychnyi posibnyk «Inkliuzyvne navchannia v zakladakh zahalnoi serednoi osvity: kerivnytstvo dlia treneriv» ["Inclusive education in general secondary education: a guide for trainers"]. K. 2018. 274 s.URL : http://posibnyk.nus.org.ua/theme-4-features-organizationinclusive-educational-environment-principles/ [in Ukrainian].

7. Onypchenko O.I., Drahunova T.O., (2021) Ihrashky, yaki vchat tolerantnosti [Toys that teach tolerance]. Genderna polityka ochyma ukrainskoi molodi: materialy pidsumkovoi konferentsii XV Rehionalnoho naukovoho konkursu molodykh vchenykh, Kharkiv, 28 kvitnia 2021 r. / [za zah. red. : N. V. Bibik, H. H. Fesenko] ; Kharkiv. nats. un-t misk. hosp-va im. O. M. Beketova. Kharkiv : KhNUMH im. O. M. Beketova. 268 s. S. 89-92. [in Ukrainian].

8. Seredovyshche, shcho nalezhyt ditiam [Environment that belongs to children]: poradnyk dlia pedahohiv zakladiv doshkilnoi osvity. K., 2019.81 s. [in Ukrainian].

9. Technologies of creative rehabilitation of children with disabilities [Technologies of creative rehabilitation of children with disabilities]/ comp. : A. S. Donchenko, E. N. Filippova, N. V. Kholmatova. URL : https://depsr.admhmao.ru/upload/iblock/79e/7._tekhnologiya_ tvorcheskoy_reab._detey_s_ogranich._vozmozh..pdf [in Russian].

10. Khubulava GG Disabled child and society: relationships and socialization [Disabled child and society: relationships and socialization]. Orthopedics, traumatology and reconstructive surgery of children. URL : file:///C:/Users/User/AppData/Local/Temp/7071-7932-2-PB.pdf [in Russian].

11. Volkova K., Bieloliptseva O., (2021) Preparation of future pedagogical and social specialists for professional activity in inclusive and gender sensitive environment: Modernization of the pedagogical system of tertiary education in higher education institutions : collective monograph. Kharkiv: Publishing house Education and Science s.r.o., 2021. C. 213-236.[in English]. 